УДК 342.9

DOI https://doi.org/10.32837/pyuv.v0i2(27).195

\author{
H. Ю. Гуть \\ кандидат юридичних наук, \\ доиент кафедри конституиійного права \\ Київського національного університету ілені Тараса Шевченка
}

\title{
ВПЛИВ ДЕРЖАВНО-ПРАВОВИХ ЯВИЩ НА ЗОВНІШНС СЕРЕДОВИЩЕ У КОНТЕКСТІ ВИЗНАЧЕННЯ ФУНКЦІЙ АДМІНІСТРАТИВНОГО ПРОЦЕСУ
}

Теорія держави та права пропонує велику кількість цікавих та достатньою мірою обгрунтованих концепцій щодо визначення функції як категорії юридичної науки. Найбільш розповсюдженим підходом в юридичній науці є визначення функції як напряму дії чи впливу державно-правового явища (наприклад, держави, права, державного органу, галузі права тощо).

Слабкість цієї концепції полягає, по-перше, в тому, що жоден представник даного наукового напряму так і не спромігся пояснити методологічне значення поняття «напрям дії (впливу)», по-друге, ця концепція не розглядає державно-правове явище, яке реалізує певні функції, як системне явище, адже, наприклад, реалізація правоохоронної функції Національної поліції може страждати від того, що один із їі підрозділів був реорганізований чи взагалі ліквідований, а функції, які він виконував, перестали тимчасово або постійно здійснюватися. Тобто зовнішні функції, що виконує Національна поліція, завжди будуть залежати від якості реалізації функцій окремими її підрозділами як елементами загальної системи.

Водночас цікавою є не тільки аргументація представників даного наукового підходу стосовно визначення поняття «функція», а й ті результати, до яких вони прийшли в ході дослідження.

3 огляду на це важливим є аналіз думок науковців, які розглядають функцію як напрям дії чи впливу державно-правового явища, особливо в контексті визначення функцій адміністративного процесу.

Загальні підходи до визначення поняття «функція» та обгрунтування функцій адміністративного процесу розкриваються у працях В.Б. Авер'янова, В.М. Бевзенко, Ю.П. Битяка, А.С. Васильєва, Т.О. Коломоєць, О.В. Кузьменко, Є.В. Курінного, П.С. Лютікова, О.М. Миколенко, Ю.В. Пирожкової, С.Г. Стеценка, В.А. Юсупова та інших вчених. Проте більшість науковців, які досліджують функції окремого державно-правового явища (наприклад, адміністративного права, адміністративної відповідальності, адміністративно-правової норми тощо), уникає дискусій щодо визначення змісту поняття «функція» і бере за основу найбільш розповсюджений в теорії права та адміністративному праві підхід. По-перше, це пояснюється тим, що науковець хоче зосередитись саме на аналізі функцій конкретного державно-правового явища і не гаяти часу на теоретичні суперечки щодо змісту того чи іншого поняття. По-друге, рівень знань частини науковців не дозволяє втрутитись у дискусію та здійснити критичний аналіз запропонованих в юридичній літературі думок, а тому дослідник приєднується до найбільш розповсюдженої думки в доктрині адміністративного права і процесу. Вважаємо, що таким фактам у юридичній науці не повинно бути місця. Результат будь-якого дослідження залежить від тієї основи, 3 якої починається дослідження. Термінологія, яка лежить в основі дослідження, теж суттєво впливає на остаточні висновки науково-дослідної праці. Якщо науковець приєднується до якогось наукового підходу чи концепції, то його вибір не повинен аргументуватися лише тим, що цей науковий підхід чи концепція $€$ найбільш розповсюдженими в юридичній науці.

Отже, огляд основних положень найбільш розповсюдженого в юридичній науці підходу до визначення функції буде корисним для розвитку юридичної науки, а також для розвитку уявлень про функції адміністративного процесу в теорії адміністративного права.

Основними завданнями, розв'язанню яких присвячена ця стаття, є такі:

1) розкрити зміст наукового підходу, згідно 3 яким функція в юридичній науці визначається як напрям дії чи впливу державно-правового явища;

2) здійснити критичний аналіз даного наукового підходу у контексті визначення функцій адміністративного процесу.

Визначення функції як напряму дії (впливу) кого- чи чого-небудь сформувалося ще в радянській доктрині права. Наприклад, С.С. Алексєєв зазначав, що функції права - це напрями його впливу з впорядкування суспільних відносин [1, с. 191]. По-перше, сам процес впорядкування чи організації суспільних відносин можна розглядати як напрям впливу права. Тобто функція впорядкування (іншими словами, організаційна функція) полягає у тому, що право здійснює організаційний вплив на суспільні відносини. По-друге, визначення, запропоноване С.С. Алексєєвим, ігнорує результат впливу як один із обов'язкових 
елементів будь-якої функції. Отже, маємо справу з ідеалістичним сприйняттям ролі права у суспільстві, коли достатньо визначитись з напрямом впливу, щоб закони та підзаконні акти виконувались у суспільстві. Поняття «функція» не має бути мертвою теоретичною конструкцією, про яку $€$ розгалужені уявлення у науковців-юристів, але яка ні в правотворчій, ні в правозастосовній сфеpax не використовується, бо це поняття сприймається юристами-практиками як міфічний термін (тобто як вигадка).

У сучасних дослідженнях визначення функції як напряму дії чи впливу набуло розвитку. Саме визначення ускладняється та стає більш громіздким, але в ньому незмінним залишається підхід, згідно з яким функція - це напрям дії чи впливу. Наприклад, Ю.В. Пирожкова стверджує, що існує багато визначень функцій адміністративного права, всі вони є обгрунтованими та затребуваними наукою і практикою. Водночас серед чисельних визначень вона пропонує розглядати функцію адміністративного права як вектор (цілеспрямований напрям) впливу адміністративного права на суспільні відносини, що направлений на досягнення бажаного, запрограмованого результату [2, с. 394].

Слід зазначити, що Ю.В. Пирожкова на відміну від С.С. Алексєєва:

- звернула увагу на необхідність розгляду результату як одного із важливих понять, яке характеризує функції адміністративного права. Саме тому у визначенні функції вчена використовує словосполучення «запрограмований результат»;

- використала системний підхід як до самих функцій адміністративного права, так і до адміністративного права як системи нормативно-правових норм. Це дозволило їй, по-перше, запропонувати багаторівневу систему функцій адміністративного права, по-друге, окремо виділити та охарактеризувати не тільки функції адміністративного права, а й функції правових інститутів адміністративного права та адміністративно-правових норм як елементів системи адміністративного права [2, с. 186].

У сучасні юридичній літературі можна знайти праці, в яких з часом мало що змінилося при визначенні функцій права. Наприклад, Н.В. Іванюта пропонує функції господарського процесуального права визначати як «<...> певні напрями впливу господарських процесуальних норм, зумовлених суспільними відносинами з вирішення господарських спорів та інших правових питань, які в результаті забезпечення функціональних зв'язків між об'єктами господарського процесуального права та іншими його правовими компонентами спрямовані на певний результат в межах здійснення справедливого судового захисту порушених, невизнаних або оскаржуваних прав і охо- ронюваних законом інтересів фізичних та юридичних осіб» [3, с. 33]. Слід підкреслити той факт, що Н.В. Іванюта у своєму визначенні теж звернула увагу на необхідність розгляду результату як одного із важливих понять, яке характеризує функції господарського процесуального права. Проте до запропонованого визначення є суттєві зауваження.

По-перше, визначення функцій господарського процесуального права є занадто громіздким i містить зайві судження та висновки. Наприклад, авторка стверджує, що господарські процесуальні норми зумовлені суспільними відносинами з вирішення господарських спорів та інших правових питань. Існування всіх норм права (норми адміністративного процесуального права не $є$ в цьому контексті винятками) зумовлене суспільними відносинами. Пояснюється це постулатом із теорії права, який проголошує: «Система права $є$ об'єктивною». Наприклад, О.В. Сурілов зазначає, що система права є об'єктивною, оскільки вона визначається структурою предмета правового регулювання, тобто суспільними відносинами, які теж мають об'єктивний характер [4, с. 218]. Отже, визначення побудоване так, що суб'єкт, який знайомиться 3 ним, постійно відволікається на судження, що вже давно визначені в теорії права та сприймаються як аксіоми. При цьому сутність функцій господарського процесуального права так і не була розкрита.

По-друге, у визначенні відбулося ототожнення функцій господарського процесуального права як цілісної системи і функцій господарських процесуальних норм як одного із найменших елементів цієї системи. Це свідчить про те, що Н.В. Іванюта не розглядає у науково-дослідній роботі господарське процесуальне право як систему. Тому, на жаль, весь аналіз функцій звівся до характеристики зовнішніх проявів господарського процесуального права.

По-третє, багато функцій, які притаманні національному праву загалом як соціальному явищу (наприклад, політична, економічна, інформаційна тощо), розглядаються на рівні окремої галузі права. Ці функції притаманні всім галузям права без якихось значних відмінностей, а тому повинні досліджуватись на рівні теорії держави та права. На галузевому рівні необхідно розглядати лише ті функції, які реалізуються лише однією галуззю права чи реалізуються декількома галузями, але кожна із них має суттєві особливості в реалізації тієї самої функції. Подібний підхід було використано і в дисертації Ю.В. Пирожкової, яка цілий розділ присвятила характеристиці загальносоціальних функцій адміністративного права (економічна, політична, соціально-культурна), але інноваційних і революційних висновків у цьому розділі дисертації запропоновано не було [2, c. 369-371]. 
Отже, не дивно, що визначення функцій державно-правових явищ через використання словосполучення «напрям дії чи впливу» піддається постійній критиці. Наприклад, ще у 80 -х роках минулого століття представники цивільного права зазначали, що судження про напрями впливу прав без вказівки конкретних об'єктів та результатів такого впливу виявляються неможливими для перевірки та мають абстрактний характер [5, с. 13].

Більш послідовно ця концепція критикується у працях О.М. Миколенко. Вчена зазначає, що такий підхід до функцій адміністративного чи адміністративно-деліктного права не дає можливості теоретичні положення науки адміністративного права перенести у правотворчу і правозастосовну сфери, тому пропонує розглядати функції адміністративно-деліктного права як єдність трьох самостійних понять - «ціль правового регулювання», «правові засоби досягнення цих цілей», «результат, який був отриманий і який повинен відповідати поставленим цілям» [6, с. 264-265]. Погоджуючись 3 думками О.М. Миколенко, вважаємо, що відсутність практично-прикладного значення - це не єдиний недолік визначення функцій державно-правових явищ через використання словосполучення «напрям дії чи впливу».

Наприклад, при розгляді функцій адміністративного процесу ця концепція була б малоефективною з таких причин:

- вона не розглядає державу, право, державний орган чи галузь права, які реалізують відповідні функції, як системне явище, де кожний елемент системи приймає участь у реалізації загальних функцій шляхом виконання своїх внутрішніх системних функцій. Саме тому важливо визначитись із поняттям «адміністративний процес» як із системним явищем. У юридичній науці відомі випадки, коли адміністративний процес ототожнювався, по-перше, з адміністративним процесуальним правом і визначався як система адміністративних процесуальних норм, по-друге, з правовідносинами, що складаються під час здійснення адміністративного судочинства (структура правовідносин складається із трьох елементів - суб'єкта, об'єкта та змісту), по-третє, з формою діяльності органу держави, яка має поетапну реалізацію (структура адміністративного процесу складається із проваджень, стадій, етапів та окремих процесуальних дій);

- вона зосереджена на зовнішніх проявах системного явища й ігнорує: а) його внутрішні зв'язки; б) вплив кожного із елементів системи на реалізацію функцій системи в цілому; в) особливості реалізації специфічних функцій окремими елементами всередині системи. Наприклад, якщо адміністративний процес розглядати як форму діяльності судової гілки влади, то доречно буде говорити про елементи, що становлять внутріш- ню структуру адміністративного процесу, та про функції, які притаманні певному виду провадження чи стадії адміністративного судочинства;

- вона має лише інтуїтивну основу і позбавлена науково-методологічного підгрунтя. Це призводить до того, що теоретичні напрацювання неможливо перенести у практично-прикладну площину і вони сприймаються як міфічні знання (тобто як вигадка).

На підставі проведеного дослідження можна зробити такі висновки.

1. Визначення функції як напряму дії чи впливу державно-правового явища $\epsilon$ найбільш розповсюдженим науковим підходом в юридичній літературі, який використовується, наприклад, під час характеристики держави, права, державного органу, галузі права тощо. Науковці ж, які досліджують функції окремого правового явища, часто уникають дискусій щодо визначення змісту поняття «функція» і беруть за основу науковий підхід, найбільш розповсюджений в юридичній науці. Результат будь-якої наукової праці залежить від термінології, яка лежить в основі дослідження. Тому важливо, щоб приєднання автора до однієї із представлених в юридичній науці думок не аргументувалось лише тим, що цей науковий підхід чи концепція є найбільш розповсюдженими в юридичній науці.

2. Розглянута концепція має такі суттєві недоліки:

а) вона не розглядає державу, право, державний орган чи галузь права, які реалізують відповідні функції, як системне явище, де кожний елемент системи приймає участь у реалізації загальних функцій шляхом виконання своїх внутрішніх системних функцій;

б) вона зосереджена на зовнішніх проявах системного явища й ігнорує його внутрішні зв'язки, вплив кожного із елементів системи на реалізацію функцій системи в цілому, особливості реалізації специфічних функцій окремими елементами всередині системи;

в) вона має лише інтуїтивну основу і позбавлена науково-методологічного підгрунтя. Це призводить до того, що теоретичні напрацювання неможливо перенести у практично-прикладну площину, тому знання про функцію сприймаються як міфічні (тобто як вигадка).

\section{Jimepamypa}

1. Алексеев С.С. Общая теория права : учебник. В 2 т. Т. 1. Москва : Юрид. лит., 1981. 361 с.

2. Пирожкова Ю.В. Теорія функцій адміністративного права : дис. ... докт. юрид. наук ; Запорізький національний університет. Запоріжжя, 2017. 543 с.

3. Сурилов А.В. Теория государства и права : учеб. пособие. Киев ; Одесса : Высшая школа, 1989. 439 с.

4. Пугинский Б.И. Функции гражданско-правовых средств. Вестник МГУ. 1980. № 1. С. 12-14. 
5. Миколенко 0.М. Функції адміністративно-деліктного права (теоретико-правовий аспект) : дис. ... докт. юрид. наук : 12.00.07 "Адміністративне право і процес; фінансове право; інформаційне право» ; Запорізький національний університет. Запоріжжя, 2018. 484 с.

\section{Анотація}

Гуть Н. Ю. Вплив державно-правових явищ на зовнішнє середовище у контексті визначення функцій адміністративного процесу. - Стаття.

$\mathrm{V}$ роботі характеризується один із розповсюджених в юридичній науці підходів, який визначає функцію як напрям дії чи впливу державно-правового явища. Зазначається, що більшість науковців, які досліджують функції, часто уникає дискусій щодо визначення змісту поняття «функція» $\mathrm{i}$ бере за основу науковий підхід, найбільш розповсюджений в юридичній науці. Констатується, що результат будь-якої наукової праці залежить від термінології, яка покладена в основу дослідження. Тому важливо, щоб приєднання автора до однієї із представлених в юридичній науці думок не аргументувалось лише тим, що цей науковий підхід чи концепція є найбільш розповсюдженими в юридичній науці. Науковий підхід, згідно 3 яким функція визначається як напрям дії чи впливу державно-правового явища, має суттєві недоліки. По-перше, він не розглядає державу, право, державний орган чи галузь права, які реалізують відповідні функції, як системне явище, де кожен елемент системи приймає участь у реалізації загальних функцій шляхом виконання своїх внутрішніх системних функцій. По-друге, він зосереджує увагу на зовнішніх проявах системного явища й ігнорує: 1) його внутрішні зв'язки; 2) вплив кожного із елементів системи на реалізацію функцій системи в цілому; 3) особливості реалізації специфічних функцій окремими елементами всередині системи. По-третє, науковий підхід, що аналізується у статті, має лише інтуїтивну основу і позбавлений науково-методологічного підгрунтя. Це призводить до того, що теоретичні напрацювання неможливо перенести у практично-прикладну площину, тому знання про функцію сприймаються як міфічні (тобто як вигадка).
Ключові слова: адміністративний процес, функція як категорія адміністративного права, вплив державно-правових явищ, функції адміністративного процесу.

\section{Summary}

$H u t N$. Yu. Influence of state and legal phenomena on the external environment in the context of determining the functions of the administrative process. - Article.

The work characterizes one of the approaches widely used in legal science, which defines function as the direction of action or influence of the state-legal phenomenon. It is noted that most scholars who study functions often avoid discussions about defining the meaning of the concept of "function" and take as their basis the scientific approach most widely used in legal science. It is stated that the result of any scientific work depends on the terminology that underlies the study. It is therefore important that the author's attachment to one of the views presented in legal science is not justified by the fact that this scientific approach or concept is the most widespread in legal science. The scientific approach according to which a function is defined as a direction of action or influence of a state-legal phenomenon has significant disadvantages. First, it does not consider a state, a law, a public authority or a branch of law that performs relevant functions as a systemic phenomenon, where every element of the system participates in the implementation of general functions by performing its internal systemic functions. Second, it focuses on the external manifestations of the systemic phenomenon and ignores: 1) its internal connections; 2) the influence of each of the elements of the system on the implementation of the functions of the system as a whole; 3 ) features of implementation of specific functions by individual elements in the middle of the system. Third, the scientific approach analyzed in the article has only an intuitive basis and is devoid of scientific and methodological basis. This leads to the fact that theoretical developments can not be transferred to the practically applied plane, knowledge of the function is perceived as mythical (i.e., as a fiction).

Key words: administrative process, function as a category of administrative law, influence of state-legal phenomena, functions of administrative process. 